\title{
Mycoflora and germination of maize seed 1,2
}

\author{
Paul R. Hepperly ${ }^{3}$, Linda Wessel-Beaver ${ }^{4}$ and \\ César Cardona-Castro
}

\begin{abstract}
Six populations of hard endosperm opaque maize were evaluated with 2 local normal maize populations at Lajas and Isabela, Puerto Rico, from March to May 1983. Corn entries were either i) inoculated with pink mold at $\mathbf{7}$ to 10 days after anthesis, ii) sprayed with benomyl at the same date and 14 days thereafter, or iii) not treated. Insect damage, caused mostly by corn earworm (Heliothis zea), and visible mold were assayed on cobs before shelling. Shelled seeds were surface-disinfected and planted on potato dextrose agar for assay of germination and infernally seed-borne mycofiora. At Lajas $6.3 \%$ of the cob area showed earworm damage, and 3.8 kernels/cob had visible mold. Natural infection with pink mold was high (53.8\%), and seed germination was low (68.6\%). At Isabela, $0.1 \%$ and $8.3 \mathrm{kernels} / \mathrm{cob}$ were damaged by earworm and molds, respectively. Seed germination was high $(93.9 \%)$ at isabela and incidence of internally seed-borne pink mold was low (17.2\%). The dominant fungus at Isabela was Cephalosporium acremonium $(32.8 \%)$. Seeds infected with this species were exceptionally vigorous and lacked roof discoloration typical of seedlings infected by the other fungi. Ear-silk inoculations increased seed-borne pink mold infection by $25 \%$ at Lajas and over $100 \%$ in Isabela. Incidence of moldy kernels was also increased by inoculation. Ear-silk application of benomyl in field plants did not reduce seed-borne infections by fungi. The same treatment increased earworm damage. Percentage earworm damage over both sites was $4.4,3.0$, and $2.1 \%$ for the benomyl, nontreated, and pink mold inoculated treatments, respectively. Benomyl applied directly to corn seed controlled all major corn-seed molds except Curvularia lunata, a benomyl-tolerant species. Higher visible seed mold was found in modified opaque corn (cv. White H. E.) than in the other entries. A local flint corn (cv. Mayorbela) suffered the least damage from both visible mold and insects. Among the hard endosperm opaque populations, Amarillo Dentado QPM-2 showed the best visible seed quality.
\end{abstract}

\section{RESUMEN}

La semilla de maíz y su micoflora y germinación

Se evaluaron seis siembras de maíz opaco modificado desarrollados por el Centro Internacional de Mejoramiento de Maíz y Trigo (CIMMYT) y

${ }^{2}$ Manuscript submitted to Editorial Board 20 June 1988.

${ }^{2}$ This research was supported in part by the U.S. Department of Agriculture CSRS Special Grant No. 82-CSRS-2-2216 under the management of the Caribbean Basin Advisory Group (CBAG). Portions of this paper are components of the M.S. dissertation of the junior author.

${ }^{3}$ Former Associate Professor of Plant Pathology; presently Plant Pathologist, USDAARS, TARS.

"Associate Professor of Agronomy.

${ }^{5}$ Former Graduate Research Assistant, Department of Agronomy and Soils. 
dos de maiz corriente local en Lajas e isabela durante los meses de marzo a mayo en 1983. Las siembras fueron: i) las barbas inoculadas con el moho rosado 7 a 10 días después de la floración; ii) asperjadas con benomil dirigida a la mazorca en la misma fecha y 14 días después; iii) testigos sin tratar. Se anotó el número de granos con hongos visibles por mazorca $y$ el porcentaje $y$ el número de granos con hongos visibles por mazorca y el porcentaje de los granos dañados por insectos, mayoramente el gusano de la mazorca de maiz (Heliothis zea). En pruebas in vitro se deferminó la viabilidad de las semillas (germinación) y la frecuencia de infecciones por hongo que sobrevivió el trałamiento de la semilla con cloro. En Lajas, $6.3 \%$ de las semillas se dañarons por insecros y 3.8 semillas por mazorca tenían hongos visibles (mohosos). La infección de semilla por Fusarium moniliforme llegó a un $\mathbf{5 3 . 5 \%}$ y se asoció esía alta incidencia con la baja tasa de germinación de al semilla $(68.6 \%)$. En Isabela, 8.3 semillas por mazorca tenían hongo y $0.1 \%$ de la semilla se dañóa por gusanos. La infección de semilla por $F$. moniliforme era baja $(17.2 \%)$ y se asoció con una alta tasa de germinación (93.9\%). Cephalosporium acremonium $(32.8 \%)$ fue el hongo dominante en Isabela. Semillas infectadas con este hongo mostr aron un vigor excepcional y no tenían las raíces descoloridas, lo cual ocurre con los otros hongos. En comparación con los testigos, la inoculación con el moho rosado aumentó la incidencia de infección en la semillas un $25 \%$ y más de $100 \%$ en Lajas e Isabela, respectivamente. La inoculación aumentó también el número de semillas con hongos. La aplicación de benomil a la mazorca no mosfró una represión efectiva de hongos en la semilla y aumentó el daño por el gusano de la mazorca. El daño por insecto fue $4.4,3.0$ y $2.1 \%$ en los tratados con benomil, en los no tratados y en los inoculadios, respectivamente. La aplicación de benomil a la semilla reprimió bien los hongos principales menos Curvularia lunata, que es una especie tolerante al benomil. La siembra de White H. E., genía más semillas con hongos visibles que las otras. Se observó mejor calidad de la semilla en Amarillo Dentado QPM-2 y Mayorbela, pero no era una diferencia esradísticamente significativa.

\section{INTRODUCTION}

In the $1960 \mathrm{~s}$, researchers discovered a mutant field corn bearing high levels of lysine and tryptophan in their seeds. These essential amino acids are usually deficient in maize-based diets. Utilization of the opaque2 endosperm mutant gene can greatly improve the value of maize in human and animal diets. Investigators during the 1970s associated mutant endosperm with a series of agronomic deficiencies, including low yield, increased mechanical damage to seed, and most importantly increased susceptibility to insects and ear rots $(9,10,12)$. Confronted with these obstacles, most corn-research organizations eliminated their studies of high protein quality maize. Nevertheless, some workers have found that the deficiencies of the mutant corn could be overcome by using modifier genes to improve kernel texture in mutant endosperms $(2,12)$.

During the $1970 \mathrm{~s}$, The International Center for Corn and Wheat Improvement (CIMMYT) researchers showed that nonmodified mutant endosperm corns yield 20\% less than normal counterparts. However, over a period of 10 years genetically modified mutants attained yields and agronomic quality comparable to those of the best normal corn popula- 
tions (2). Modified opaque populations are phenotypically indistinguishable from normal corn; however, they maintain the superior amino acid composition of mutant opaque-2 corn. Modified opaques and mutant opaques give similar improvements in corn diets. High protein quality corn has enormous unexploited potential.

From the first introduction of opaque mutant corn, increased seed molds were seen as a major objection to their use. Corn seed mold can lower corn yield, quality, and market acceptance. Feeding moldy grain often leads to poor animal performance and illness. Aflatoxin from Aspergillus flavus can cause serious animal health problems in dosages of only a few parts per billion. In the southeastern United States aflatoxins in corn cause million dollar losses, especially when high temperature, drought, and insect attack predispose plants and warm humid conditions prevail near harvest $(5,7)$. Aflatoxin probably causes more serious problems to human and animal health in developing tropical countries because environmental conditions are generally more favorable for Aspergillus flavus growth and development.

We will report corn seed viability, incidence of seed mold, and severity of ear damage in normal adapted corn varieties and in modified opaque germplasm under western Puerto Rican conditions.

\section{MATERIALS AND METHODS}

Field Trials-From March to May 1983 eight populations of maize were planted and grown at the Isabela and Lajas Research and Development Centers of the University of Puerto Rico College of Agricultural Sciences. Both sites are located in western Puerto Rico, but differ in their soils and climatic conditions. Isabela, located in the northwest, has a sub-humid climate with a mean precipitation of approximately $1.6 \mathrm{~m}$ annually. The soil, an Oxisol, has variable soil pH (mean 5.5) and low inherent fertility. Lajas, in the southwest, has a semi-arid climate, approximately $1.0 \mathrm{~m}$ yearly precipitation, and a highly fertile Vertisol with $\mathrm{pH}$ approximately 7.0 .

The eight corn populations consisted of six modified opaque-2 populations from CIMMYT, in Mexico and two normal corn genotypes from Puerto Rico supplied by Dr. A. Sotomayor-Ríos of the Tropical Agriculture Research Station (TARS) in Mayagüez. Wessel-Beaver et al. (11) have described these genotypes and provided information on their agronomic potential.

A randomized complete block design with split plots was used with three replications of each corn population. Plots consisted of six 10-m rows with $0.9-\mathrm{m}$ spacings between rows. The experiments were hand planted and thinned manually to a final stand of 43,000 plants/ha. Fertilization consisted of $500 \mathrm{~kg} / \mathrm{ha}$ of 15-5-10 commercial fertilizer which was 
broadcast and disk incorporated prior to planting, and side-dress application of $400 \mathrm{~kg} / \mathrm{ha}$ of urea applied 35 days after planting. Soil insects were controlled by carbofuran at $3.4 \mathrm{~kg}$ ai/ha. Methomyl at $1 \mathrm{~kg}$ ai/ha was applied in aqueous solution twice during grain-fill to help control ear insects. Alachor, at $2 \mathrm{~kg}$ ai/ha, applied pre-plant, and a post-plant applieation of glyphosate at $1 \mathrm{~kg}$ ai were used for weed control.

Plots were split into three sub-treatments: i) non-inoculated and nonsprayed control, ii) pink mold inoculated, and iii) benomyl sprayed. For pink mold inoculations, Fusarium moniliforme Sheldon was isolated from infected corn seed and maintained in pure culture on potato-dextrose agar. The fungus was increased in 2-L Erlenmeyer flasks containing $300 \mathrm{~g}$ of unpeeled dry rice, which was moistened overnight in water and autoclaved for $1 \mathrm{~h}$ before being seeded with pink mold. The inoculated flasks were incubated at $28^{\circ} \mathrm{C}$ for two weeks and conidia were harvested by washing the substrate with sterile distilled water. Aqueous suspensions were adjusted to a concentration of approximately 100,000 conidia/ml by diulution with sterile distilled water. Inoculum was applied to ear silks at approximately seven days after anthesis. The silks were trimmed by scissors leaving $2 \mathrm{~cm}$ of exposed silks for inoculation. The inoculum was administered to cut silk surfaces with a 3 -cm paint brush. Silks were covered with a waxed shoot bag to maintain high relative humidity after inoculation. The benomyl treatment was directed over the ear 10 and 25 days after anthesis at the rate of $1 \mathrm{~kg}$ ai/ha.

After harvested corn ears were examined for insect damage and the estimated area damaged was recorded, ears were sampled and grains with visible mold were counted.

In vitro Seed Quality Assays-Shelled corn from each subplot was sampled to obtain 100 random seeds for quality assays. Test seeds were submerged in $0.5 \%$ aqueous sodium hypochlorite solution and dried aseptically under a laminar flow hood. Dried seed were aseptically transferred (five per plate) to potato-dextrose agar in sterile 9 -cm plastic petri dishes. Plates were incubated at $26^{\circ} \mathrm{C}$ for two weeks. Frequencies of fungal infections and seed germination were then determined.

In vitro Seed Treatment-Benomyl activity toward corn seed molds was tested in corn seed from the Isabela trial. Benomyl in powder (Benlate $50 \mathrm{~W}$, registered trademark E. I. Du Pont de Nemours and Company, Wilmington, Delaware 19898, 50\% methyl 1-(butylcarbamoyl)-2benzimidazolecarbamate active ingredient) was applied at a rate of $1 \mathrm{~g}$ ai $/ \mathrm{kg}$ of shelled corn seed. Seeds were plated on sterile potato dextrose agar as described above. Nontreated seeds, which were surface disinfected and plated as previously described, served as controls. Each treatment included four replications of 100 seed each. The replicates were arranged in a complete randomized design in the incubator. Seed germi- 
nation, and the frequency and type of fungal infections for both treatments, were determined by the process as described for in vitro quality assays.

\section{RESULTS}

Lajas-Overall 3.8 kernels/cob showed visible mold. Visible mold ranged from 2.2 kernels/cob for Diente de Caballo to 5.5 kernels/cob for White H. E. (table 1). Amarillo Dentado QPM-2 had the lowest mold among the modified corn genotypes (2.5 kernels/cob), significantly less than White H. E. (5.5 kernels/cob), Amarillo Cristalino (5.3 kernels/cob), and Tuxpeno-1 (4.9 kernels/cob. Inoculation with pink mold significantly increased the number of moldy grains, 4.6 kernels/cob, compared with 3.5 kernels/cob for the non-treated control and 2.8 kernels/cob for fungicide-treated corn ears.

Overall $5.7 \%$ of the cob area showed ear feeding by insects, particularly by corn ear worm (table 1). The area of the cob showing earworm damage was significantly greater when ears were treated with benomyl (table 2). Insect damage was significantly lowered by pink mold inoculation.

Overall seed germination was low $(66.0 \%)$, and total infection frequency was high (115.5\%) (table 3). Fungal incidence exceeded $100 \%$ because more than one mold colony was found on many seeds. Ten fungal

TABLE 1.-Mean number of moldy kernels of corn per ear and percentage of kernels consumed by insects in modified opaque and normal corn populations grown in Lajas and. Isabela March through May 1993

\begin{tabular}{lccccc}
\hline & \multicolumn{2}{c}{ Lajas } & & \multicolumn{2}{c}{ Isabela } \\
\cline { 2 - 3 } \cline { 5 - 6 } \multicolumn{1}{c}{ Population } & $\begin{array}{c}\text { No. } \\
\text { moldy }\end{array}$ & $\begin{array}{c}\text { Insect } \\
\text { damage }\end{array}$ & & $\begin{array}{c}\text { No. } \\
\text { moldy }\end{array}$ & $\begin{array}{c}\text { Insect } \\
\text { damage }\end{array}$ \\
\hline Diente de Caballo & 2.2 & 5.4 & -- & - \\
Mayorbela & 2.9 & 6.4 & & 6.5 & 0.09 \\
White H.E. 02 & 5.5 & 6.6 & & 15.4 & 0.13 \\
Amarillo Dentado & & & & \\
QPM-1 & 3.5 & 5.4 & & 7.4 & 0.08 \\
Tuxpeño-1 QPM & 4.9 & 5.3 & & 8.7 & 0.10 \\
Pool-23 QPM & 3.9 & 4.5 & & 6.1 & 0.10 \\
Amarillo Dentado & & & & \\
QPM-2 & 2.5 & 4.9 & & 4.8 & 0.09 \\
Amarillo Cristalino & 5.3 & 7.2 & & 9.2 & 0.08 \\
PCCMCA & - & - & 9.8 & 0.09 \\
$\quad$ LSD $^{3}$ & 1.8 & NS & & 5.3 & 0.03 \\
\hline
\end{tabular}

${ }^{1}$ NS no statistically significant differences found.

2 PCCMA was a substitute normal corn for Diente de Caballo in Isabela.

${ }^{3}$ LSD Fischer's Least Significant Difference at $P=0.05$. 
TABLF 2.-The effects of benomyl applications on com ears and silk inoculation of pink mold on moldy kernels per ear and percentage of kernels consumed by insects in Lajas and Isabela March to May 1983

\begin{tabular}{lccccc}
\hline & \multicolumn{2}{c}{ Lajas $^{*}$} & & \multicolumn{2}{c}{ Isabela } \\
\cline { 2 - 3 } \cline { 5 - 6 } Treatment & $\begin{array}{c}\text { Number } \\
\text { Moldy kernels }\end{array}$ & $\begin{array}{c}\text { Insect } \\
\text { damage }\end{array}$ & & $\begin{array}{c}\text { Number } \\
\text { Moldy kernels }\end{array}$ & $\begin{array}{c}\text { Insect } \\
\text { damage }\end{array}$ \\
\hline $\begin{array}{l}\text { Nontreated } \\
\text { control }\end{array}$ & 3.5 & 5.7 & 6.9 & 0.08 \\
$\begin{array}{l}\text { Benomyl } \\
\text { treated }\end{array}$ & 2.8 & 9.1 & & 6.0 & 0.07 \\
$\begin{array}{l}\text { Pink Mold } \\
\text { inoculated }\end{array}$ & 4.6 & 3.2 & & 12.6 & 0.01 \\
Mean" & 3.6 & 6.0 & 8.5 & 0.05 \\
\multicolumn{1}{c}{ LSD } & 1.1 & 2.0 & 4.0 & 0.02 \\
\hline
\end{tabular}

'Interactions of population by locations were not significant.

"Mean values over 8 corn populations at both locations.

'LSD Fischer's Least Significant Difference at $P=0.05$.

taxa were identified from the seed: Fusarium moniliforme, two species of Penicillium, Aspergillus flavus, one species of Trichoderma, Nigrospora oryzae, botryodiplodia theobromae, Macrophomina phaseolina, and a species each of Chaetomium and Rhizopus, and miscellaneous fungi, which did not sporulate. Fusarium moniliforme was by far the most common fungus $(60 \%)$, followed by the Penicillium species and

TABLE 3.-Percentage seed infection and germination in seed from nontreated plants, from plants with benomyl applied to filling ears, and to plants whose silks were inoculated with pink mold 10 days after fower in Lajas, Puerto Rico, from March to May 198:"

\begin{tabular}{lccc}
\hline & \multicolumn{3}{c}{ Germination } \\
\cline { 2 - 4 } \multicolumn{1}{c}{ Fungus taxa } & Nontreated & Benomyl & $\begin{array}{c}\text { Pink } \\
\text { mold inoculated }\end{array}$ \\
\hline Fusarium moniliforme & 53.8 & 53.5 & 72.6 \\
Penicillium sp. (green) & 26.3 & 29.3 & 20.2 \\
Penicillium sp. (yellow) & 5.3 & 5.7 & 7.6 \\
Aspergillus flavus & 14.1 & 11.2 & 11.6 \\
Trichoderma sp. & 9.1 & 7.4 & 5.5 \\
Nigrospora oryzue & 0.3 & 0.9 & 0.2 \\
Chaetominm sp. & 0.2 & 0.1 & 0.4 \\
Botryodiplodia theobromae & 0.1 & 1.4 & 0.7 \\
Rhizopus sp. & 0.4 & 0.6 & 0.1 \\
Macrophomina phaseolina & 0.1 & 0.0 & 0.1 \\
Miscellaneous Fungi & 1.1 & 0.9 & 0.7 \\
Total Fungi & 110.8 & 111.0 & 119.7 \\
Germination & 69.0 & 68.0 & 67.0 \\
\hline
\end{tabular}

'Based on 3 repitions of 50 seed each for each of 8 corm populations.

Differences among the treatments were nonsignificant (FLSD P $=0.05$ ) with the exception of Fusarium moniliforme which was increased by inoculation.

Treatment by corn population interactions were not significant. 
Aspergillus flavus which varied from 10.7 to $22.7 \%$ infection. Pink mold inoculation significantly increased infection (72.6\%) compared with that of the nontreated control (53.8\%).

Isabela-The number of kernels/cob with visible mold averaged $5.5 \%$ overall cultivars arid treatments (table 1 ). The least mold damage was found in Amarillo Dentado QPM-2 (4.8), and the highest in White H. E. (15.4). Visible mold on White $\mathrm{H}$. E. was significantly higher than on all other populations. Less than $1 \%$ of the cob area was found damaged by insects.

The majority of the seed-borne fungi found in Lajas were also recorded in Isabela (tables 3 and 4). However, Cephalosporium acremonium was found only at Isabela, whereas Macrophomina phaseolina was detected only in Lajas. Although pink mold was by far the most frequent fungus in Lajas, $C$. acremonium was the dominant fungus in Isabela. Seed germination was high (93.9\%).

Pink mold inoculation reduced the percentage of the cob area with insect damage $(0.1 \%)$. The nontreated control had $(0.8 \%)$ damage; the benomyl treatment, $(0.7 \%)$. The inoculation also increased numbers of kernels/cob with visible mold (table 2). Pink mold inoculation more than doubled the incidence of internal pink infections (table 4) and lowered incidence of the major Penicillium species. Large reductions in the fre-

TABLE 4.-Percentage of seed infection and germination of seed from nontreated corn plants, from plants with benomyl applied to ears during grain fill, and from plants inoculated with pink mold on sillss 10 days after anthesis in Isabela, Puerto Rico, March to May 1985

\begin{tabular}{lrrr}
\hline \multicolumn{1}{c}{ Fungal taxa } & Nontreated & Benomyl & $\begin{array}{c}\text { Pink } \\
\text { mold inoculation }\end{array}$ \\
\hline Cephalosporium & & & \\
acremonium & 32.9 & 31.6 & 21.0 \\
F. moniliforme & 17.2 & 16.4 & 37.8 \\
Penicillium sp. (green) & 23.4 & 20.7 & 11.5 \\
Penicillium sp. (yellow) & 3.7 & 4.5 & 11.8 \\
Trichoderma sp. & 3.7 & 3.8 & 2.0 \\
Nigrospora oryzae & 4.6 & 3.6 & 1.4 \\
Chaetomium sp. & 6.8 & 3.9 & 0.9 \\
Botryodiplodia theobormae & 1.8 & 3.5 & 0.7 \\
Rhizopus sp. & 0.1 & 0.8 & 0.1 \\
Miscellaneous Fungi & 1.8 & 2.2 & 0.6 \\
Total Fungi & 102.6 & 100.3 & 89.7 \\
Germination & 94.5 & 93.5 & 93.8 \\
\hline
\end{tabular}

Based on 3 replications of 50 seed each for each of 8 corn populations.

Differences among treatments were nonsigniticant FLSD $P=0.05$ with the exception of decreased green Penicillium and increased yellow Penicillium following pink mold inoculations.

Corn populations by trearment interactions were not noted. 
quency of Aspergillus flavus, Trichoderma sp., Botryodiplodia theobromae, Nigrospora oryzae, Chaetomium sp., Rhizopus sp., and C. acremonium were found after pink mold inoculation (table 4).

Seed germination was higher at Isabela (93.9\%) than in Lajas (68.2\%). The low germination found at Lajas was associated with higher insect damage and pink mold infections than were found in Isabela (tables 3 and 4). Cephalosporium acremonium was the dominant fungus on corn seed in Isabela, and infected seeds showed extraordinary vigor in the in vitro assay. High germination in Isabela was associated with high incidence of C. acremonium, low incidence of pink mold, and low incidence of insect damage.

Pink mold inoculation significantly increased pink mold seed infection while reducing recovery of the majority of other fungi found on corn seed. In both trials, pink mold inoculation lowered seed germination (79.3\%) from that of the nontreated control (82.1\%) (table 5). This effect was most notable in Lajas, where pink mold incidence greatly exceeded that in Isabela. From these trials, it appears that pink mold infections begin reducing seedlot germination when incidence exceeds $40 \%$.

In Vitro Seed Treatment with Benomyl-Benomyl applied topically was highly effective in reducing the recovery of seed-borne fungi in corn (table 6). Fungal incidence on corn seed was lowered from over $80 \%$ on nontreated seed to less than $2 \%$ on benomyl treated counterparts. Benomyl controlled all fungal species observed except Curvularia lunata, which is known for its tolerance to benomyl. Germination of benomyltreated seeds was $100 \%$, as compared with $95.8 \%$ for control seed.

\section{DISCUSSION}

A major objective of our trials was to evaluate whether modified (hard endosperm) opaque populations would react differently to seed

TABLE 5.-Percentage of seed infection and germination in seed from nontreated corn plants, from plants with benomyl applied to filling ears, and to plants inoculated with pink mold on silks 10 days after anthesis over combined sites (Isabela and Lajas, Puerto Rico) March to May $1985^{1}$

\begin{tabular}{lcccc}
\hline \multicolumn{1}{c}{ Fungal taxa } & Nontreated & Benomyl & $\begin{array}{c}\text { Pink } \\
\text { mold inoculation }\end{array}$ & FLSD $^{2}$ \\
\hline Fusarium moniliforme & 35.7 & 35.4 & 51.1 & 0.7 \\
Penicillium sp. (Green) & 23.9 & 23.4 & 14.7 & 1.2 \\
Penicillium sp. (Yellow) & 4.1 & 4.2 & 13.9 & 0.8 \\
Aspergillus flavus & 9.2 & 10.8 & 6.3 & 0.8 \\
Trichoderma sp. & 6.4 & 6.0 & 3.6 & 0.9 \\
Germination & 82.1 & 81.7 & 79.3 & 0.3 \\
\hline
\end{tabular}

${ }^{1}$ Means based on 3 replications of 50 seeds each for each of 8 corn populations at each location.

${ }^{2}$ Probability of FLSD $=0.05$. 
TABLE 6.-Percentages of seed germination and fungal infection in corn seed from Isabela, Puerto Rico, March through May 1983, which were either treated with benomyl (g a.i.l/kg seed) or not treated prior to testing on sterile potato dextrose agar

\begin{tabular}{lcc}
\hline \multicolumn{1}{c}{ Parameter } & Nontreated & Benomyl seed treated \\
\hline Germination $^{1}$ & 95.8 & $100.0^{2}$ \\
Total Fungi & 81.7 & 1.9 \\
Botryodiplodia theobromae & 4.2 & 0.0 \\
Cephalosporium acremonizm & 23.0 & 0.0 \\
Curvularia lunata & 0.0 & 1.9 \\
Fusarium moniliforme & 15.8 & 0.0 \\
Nigrospora oryzae & 5.0 & 0.0 \\
Penicillium sp. (Green) & 14.1 & 0.0 \\
Penicillium sp. (Yellow) & 5.4 & 0.0 \\
Miscellaneous Fungi & 14.2 & 0.0 \\
\hline
\end{tabular}

'Germinations at $27^{\circ} \mathrm{C}$. Means based on 4100 -seed replicates.

${ }^{2}$ Treatment differences were significant $\mathrm{P}=00.1$ using FLSD.

pathogens and insects from normal (non-opaque) adapted corn populations. Modified opaque genotypes were not notably more susceptible to these pests from normal adapted corn, with the possible exception of White H. E., in our trials. White corn is generally more susceptible to ear and seed pests than pigmented corn, regardless of genetic modification.

Our results support the contention that generally soft endosperm corns are more susceptible to seed pests than harder endosperm types and that the biggest problem with the opaque genotypes is endosperm softness. It appears that genetic modification resolves the drawbacks of the original opaque corns through the improvement of endosperm hardness. The finding that modified opaques are not hyper-susceptible to seed and ear pests does not imply that corn production in west Puerto Rico is not constrained by these pests. Despite insecticide application to reduce corn earworm, these insects caused significant cob damage. Insects on corn ears could play a major role in the predisposition of plants to seed mold damage by providing entry points and vectoring molds $(3,6)$. In Lajas, high incidence of pink mold and Aspergillus and Penicillium species indicate that rainy season conditions in west Puerto Rico could be very favorable to the development of fungi known for their mycotoxins.

Local corn production can be constrained by production of low germination seed. Low seed germination is often strongly associated with seed infections by toxigenic fungi (4). The temperature, relative humidities, and fungal incidence in Western Puerto Rico can be expected generally to exceed those of the southeastern United States where toxigenic fungi periodically cause economic losses on feed corn (7). Our levels of total 
fungi in corn seed and incidence of $F$. moniliforme appear almost double those reported in Missouri (1).

Pink mold inoculations were successful in increasing seed infection and had nontarget action of reducing ear worms. Fungi are important insect pathogens, and $F$. moniliforme and $A$. niger infect corn ear worm naturally (8). Benomyl, which is active against $F$. moniliforme, was ineffective in controlling seed infections by means of husk applications. This ineffectiveness could arise from lack of translocation in corn, or metabolism of the compound different from that found in other crop species. Benomyl ear applications, however, increased corn ear worm damage. We suspect that benomyl controls the fungi in the silks and husks which partially control corn earworm.

C. acremonium was associated with reduced levels of pink mold and high germination and seedling vigor and corn root health. $C$. acremonium is a good biocontrol candidate meriting greater future attention. Morphologically this fungus is similar to the endophytic fungi on grasses which are known to produce alkaloids thus promoting the survival of infected plants by their deterrence of insect and animal foragers. Besides the role of these fungi as biocontrol agents, special attention should be given to their possible effects on crop quality.

As a topical seed dressing, benomyl was extremely effective in controlling most corn seed molds, including the most common toxigenic fungi. Failure of ear applications to control seed infections of sensitive fungi suggests more work is needed to understand the uptake, movement, and metabolism of benomyl in field corn.

\section{LITERATURE CITED}

1. Calvert, O. H., A. S. Foudin, H. C. Minor and G. F. Krause, 1985. Fusarium moniliforme colonization of corn ears in Missouri. Plant Disease, 69(12): 988-90.

2. Cantrell, R. P., 1986. The past experience and future course of the CIMMYT maize program. Pages 134-154: in Proc. 41th Annual Corn \& Sorghum Res. Conf. Publication 41, Am. Seed Trade Washington.

3. Carter, W., 1973. Insects in Relation to Plant Disease. John Wiley and Sons, New York.

4. Cole, R. J., J. W. Kirkey, H. G. Cutler, R. L. Doupnik and J. C. Peckham, 1973. Toxin from Fusarium moniliforme: Effects on plants and animals. Science 179: 1324-326.

5. Gray, F. A., W. F. Faw and J. L. Boudwell, 1982. The 1977 corn aflatoxin epiphytotic in Alabama. Plant Dis. 66: 221-22.

6. Hepperly, P. R. and Roberto E. Rodriguez-Cancel, 1987. Fruity aromas from pink mold and their association with insect attraction. J. Agric. Univ. P. R. 71 (3): 327-30.

7. Jones, R. K., H. E. Dunean, G. A. Payne and K. J. Leonard, 1980. Factors influencing Aspergillus flans in silk-inoculated corn. Plant Dis. 64: 859-63.

8. Kuno, G., 1975. Preliminary survey of microorganisms associated in some insects in Puerto Rico. J. Agric. Univ. P. R. 59 (1): 69-74.

9. Loesch, P. J. Jr., D. C. Foley and D. F. Cox, 1976. Comparative resistance of opaque-2 and normal inbred lines of maize to ear rotting pathogens. Crop Sci. 16: 841-42. 
10. Warren, H. L., 1978. Comparison of normal and high lysine maize inbreds for resistance to kernel rot caused by Fusarium moniliforme. Phytopathology 68: 1331-335.

11. Wessel-Beaver, L., C. Cardona Castro and P. R. Hepperly, 1988. Agronomic performance of hard endosperm opaque corn populations in Puerto Rico. J. Agric. Univ. P. R. 72 (2): 309-17.

12. Wessel-Beaver, L. and R. J. Lambert, 1982. Genetic control of modified endosperm texture in opaque-2 maize. Crop Sci. 22; 1095-098. 